\title{
The Effect of Intrinsic Rewards and Extrinsic Rewards on Performance with Job Satisfaction as Intervening Variables
}

\author{
Reno Widhi Pramono \\ Universitas Airlangga, Indonesia. \\ Email: reno.widhi.pramono-2018@pasca.unair.ac.id
}

\begin{abstract}
ARTICLE INFO
\section{Keywords:}

Rewards

Extrinsic Rewards

Intrinsic Rewards

Job Satisfaction

Performance
\end{abstract}

Date received : 12 December 2020

Revision date : 05 February 2021

Date received : 01 March 2021

\section{ABSTRACT}

The world is facing a fast global development. It requires businesses to be able to compete in any developments. Companies need to be supported by the good Performance of the employees to achieve the vision and mission of the organization. Rewards and Job Satisfaction are two variables that can influence Performance. Rewards can be either Intrinsic and Extrinsic. If both types of Rewards are high so as to form high Job Satisfaction, then it can impact Performance improvement of employees. Based on this, this research aims to analyze the influence of Intrinsic Rewards and Extrinsic Rewards to Performance with Job Satisfaction as an intervening variable. This research uses a quantitative approach. Data collection techniques used by distributing questionnaires to 52 contract employees division of Corporate Customer Access Network at PT. Telekomunikasi Indonesia, Tbk. Witel Jatim Surabaya. Sampling techniques in this research using census method. Mechanical testing of the data used in this research is SEM-PLS. Results of this research shows that Intrinsic Rewards influence positively and significantly related to Performance, while Extrinsic Rewards influemce negatively and not significantly related to Performance. The next results shows that Job Satisfaction can mediating partially the relationship of Intrinsic Rewards to Performance and mediating fully the relationship of Extrinsic Rewards to Performance

Coresponden Author:

Email: reno.widhi.pramono-2018@pasca.unair.ac.id Article with open access under license

\section{INTRODUCTION}

The company needs to be supported by good performance in achieving its vision and mission. Performance is the type of work that has been completed. Performance shows the level of achievement of a job (Byars, Lloyd. L. \& Rue, n.d.). Improved employee performance is indispensable for companies in running PR OSES businesses. Employee performance has a positive direct relationship with intrinsic rewards and extrinsic rewards. (Gohari dkk. 2013).

Rewarding has been found to be one of the organization's key policies that can improve staff performance and can improve organizational output (Ajila \& Abiola, 2004)

(McCormick \& J. Tifflin., 1979) and (Tuma \& Pratt, J. M. (1982). Clinical child psychology practice and training: A survey. VIdots of Clinical Child \& 
Adolescent Psychology, 137(August 2012), 37-41. http://doi.org/10.1037/a0022390 et al., 2002) classifies rewards into two, namely intrinsic rewards and extrinsic rewards. Higher reward and employee satisfaction within the organization play a major role in both the promotion of employee job satisfaction and higher productivity within the organization (Sarwar \& Abugre, 2013), therefore, the need to reward companies that can satisfy employees so as to encourage employees to be more productive and perform better.

Job satisfaction is one of the most important and significant variables in organizational behavior and organizational performance. The higher the job satisfaction, the more likely workers are to have a positive attitude towards their work (Wang \& Feng, 2003). Job satisfaction is expected to be a factor that can improve employee performance so that the company's productivity also increases.

Reward is one of the factors that can affect employee performance, in addition to job satisfaction can also affect the performance of employees in a company. Higher reward and employee satisfaction in work organizations play a major role in both employee job satisfaction promotions and higher productivity within the organization (Sarwar \& Abugre, 2013). The company must be able to manage employee rewards and satisfaction well in the hope of improving employee performance so that the company's productivity becomes better.

This research was conducted on pt contract employees. Telecommunications Indonesia, Tbk. Witel Jatim Surabaya corporate customer access network division. The division receives 500 complaints every day. In addition, there are also inconsistencies in the awarding of rewards in this case salaries and overtime money which is feared to be the trigger for a decrease in the performance of contract employees.

\section{Intrinsic Rewards dan Extrinsic Rewards}

Rewards is one of the strategies used by Human Resource Management to attract and retain appropriate employees and facilitate them to improve their performance. Organizational rewards include all types of rewards, both intrinsic and extrinsic, that are accepted as a result of work by the organization (Byars, Lloyd. L. \& Rue, n.d.)

(Robbins \& DeCenzo, 2002) also states that rewards are divided into two, namely intrinsic rewards and extrinsic rewards. Intrinsic rewards according to (Robbins \& DeCenzo, 2002) is a person's personal satisfaction gained from the work itself. Extrinsic rewards are rewards that include money, promotions, and benefits where rewards come from outside work and outside sources, especially management (Robbins \& DeCenzo, 2002). According to (Robbins \& DeCenzo, 2002)., intrinsic rewards and extrinsic rewards can be measured by the following indicators:

1. Extrinsic rewards:
a. Salary
b. Annual bonus
c. Incentives
d. Overtime money
e. Protection program
f. Wages for time not working
g. Suitable office furniture
h. IT-based HR Services
i. Appropriate lunch hours
j. Work assignments
k. Appreciation

2. Intrinsic rewards:
a. Participate in decision making
b. Freedom and flexibility of work
c. Trust given by the company
d. ppropriate work
e. Opportunities to develop themselves
f. Diverse work activities.

\section{Job Satisfaction}

Job satisfaction itself is an employee's general attitude towards work (Byars, Lloyd. L. \& Rue, n.d.). Other opinions of (Yarmand et al., 2017) Locke (dalam Abdullah dan Wan 2013) stated, job satisfaction as a pleasant or positive emotional state resulting from an assessment of one's performance or work experience. Job satisfaction is an emotional or affective reaction to various aspects of an individual's work situation. This has been flagged as a positive sentimental reaction resulting from employee job assessments (Kreitner dan Kinicki 2012). Job satisfaction can be measured by Minnesota Satisfaction Questionnaire (MSQ):

1. Able to stay in business throughout working hours.

2. Opportunity to use my skills in completing my work.

3. Opportunities to do diverse work.

4. The work achievements I get.

5. Expressions that others give for my work.

6. Opportunity to finish work with other coworkers.

7. Opportunity to finish the job in my own way.

8. Opportunity to work independently.

9. The duration of the employment contract provided by the company for honorer employees. 
10. Opportunity to use my own assessment of the situation in the work.

11. Opportunity to share with colleagues about what I've done.

12. Opportunity to do good things in the work.

13. The way my leadership handles its subordinates.

14. My supervisor is competent in making decisions.

15. The praise I get for my work.

16. Implementation of corporate policies in the work environment.

17. The way my coworkers get along with each other.

18. Work facilities provided according to the specifications of my work.

19. Promotional opportunities in this job.

20. The amount of work given to me..

\section{Performance}

In an organizational context, performance is usually defined as the extent to which members of an organization contribute to achieving organizational goals. Employees are a key source of competitive advantage in organization-oriented services (Stajkovic \& Luthans, 1998). Performance is also the level of fulfillment of tasks that make up the work of employees. This reflects how well an employee meets the job requirements (Byars, Lloyd. L. \& Rue, n.d.). Employee performance can contribute to the long-term survival of a company (Ellinger et al., 2008). Performance can be measured using six indicators from (Ellinger et al., 2008), I.e :

1. Get a positive response from customers.

2. Able to resolve complaints from customers.

3. Able to manage working time effectively.

4. Able to carry out standard service procedures set by the company.

5. Able to meet customer's wishes

6. Complete work targets on time.

\section{Relationships Between Variables}

Intrinsic Rewards' Relationship to Performance

Research conducted by (Ajila \& Abiola, 2004)

with research title "Influence of Rewards on Workers Performance In an Organization" stated that there is a significant relationship between intrinsic rewards and employee performance. Research conducted by Gohari dkk. (2013) with research title "The Relationship Between Rewards and Employee Performance" found that all types of rewards (including intrinsic rewards and extrinsic rewards) had a direct and positive relationship to employee performance.
$\mathrm{H} 1$ : Intrinsic rewards have a significant impact on the performance of PT contract employees. Telecommunications Indonesia, Tbk. Witel Jatim Surabaya CCAN division.

\section{Extrinsic Rewards' Relationship to Performance}

Research conducted by Gohari et al. (2013) with the title of research "The Relationship Between Rewards and Employee Performance" found that extrinsic rewards in this study had a direct relationship with employee performance. The main organizational variable used to reward employees and strengthen performance is salary. Promotions may relate to performance (Byars, Lloyd. L. \& Rue, n.d.). Other research conducted by (Ajila \& Abiola, 2004) with research title "Influence of Rewards on Workers Performance In an Organization" states that there is a positive relationship between extrinsic rewards and worker performance.

$\mathrm{H} 2$ : Extrinsic rewards have a significant impact on the performance of PT contract employees. Telecommunications Indonesia, Tbk. Witel Jatim Surabaya CCAN division.

\section{Intrinsic Rewards' Relationship to Performance with Job Satisfaction Mediation}

Research conducted by Gohari et al. (2013) with the title of research "The Relationship Between Rewards and Employee Performance" Research conducted by Gohari et al. (2013) with the title of the study found that all types of rewards (intrinsic and extrinsic) have a direct and positive relationship to employee performance. The organization's rewards system often has a significant impact on employee job satisfaction levels. For many years, generally managers believed that a satisfied employee was always a good employee. In other words, if management can keep all employees happy, good performance will automatically follow (Byars, Lloyd. L. \& Rue, n.d.).

H3: Intrinsic rewards affect performance by mediating job satisfaction in PT contract employees. Telecommunications Indonesia, Tbk. Witel Jatim Surabaya CCAN division.

\section{Extrinsic Rewards' Relationship to Performance with Job Satisfaction Mediation}

Research conducted by (Tuma, J. M., \& Pratt, J. M. (1982). Clinical child psychology practice and training: A survey. Vlots of Clinical Child \& Adolescent Psychology, 137(August 2012) et al., 2002) Gohari dkk. (2013) with research title "The Relationship Between Rewards and Employee Performance" the study title found that extrinsic 
rewards in this study had a direct relationship with employee performance. The organization's rewards system often has a significant impact on employee job satisfaction levels. For many years, generally managers believed that a satisfied employee was always a good employee. In other words, if management can keep all employees happy, good performance will automatically follow (Byars, Lloyd. L. \& Rue, n.d.).

H4: Extrinsic rewards affect performance by mediating job satisfaction in PT contract employees. Telecommunications Indonesia, Tbk. Witel Jatim Surabaya CCAN division.

\section{Conceptual Framework}

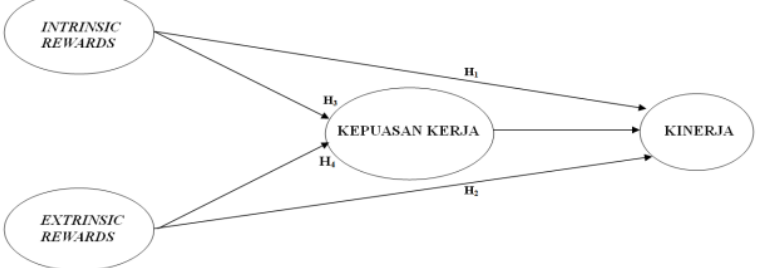

Figure 2.1

Conceptual Framework of Research

\section{METHOD}

\section{Research Methods and Approaches}

The approach used in this study is a quantitative approach. Quantitative approach focuses on testing hypotheses, the data used must be measurable, and will produce generalized conclusions. This study used data collection method with questionnaire dissemination technique to $52 \mathrm{PT}$ contract employees. Telecommunications Indonesia, Tbk. Witel Jatim Surabaya CCAN division. Sampling techniques by census. This research approach is based on theory and hypothesis, which is followed by drawing up conceptual frameworks and then identifying variables, creating operational definitions, collecting population and sample data and conducting analysis. This study used PLS (Partial Least Square) and Sobel test analysis techniques to test the effects of mediation.

\section{Variable Operational Measurement and Definition \\ Intrinsic Rewards}

The object of this research consists of principal transformational leadership (X1), which includes the dimensions of Charismatic (Idealized influence), Intellectual Stimulation, Individual consideration, and Inspirational motivation so that the $\mathrm{X} 1$ variable consists of 14 indicators; Teacher Work Culture (X2) includes dimensions of aspects of loyalty, discipline, commitment, leadership, aspects of work performance so that the variable X2 consists of 24 indicators. Teacher Performance $(Y)$ includes Education and Teaching dimensions, Conducting research and Knowledge Development by teachers, Community Service, Professional Attitude so that the $Y$ variable consists of 28 indicators.

\section{Extrinsic Rewards}

Measurement and Definition of Variable OperationsExtrinsic rewards can be defined as financial and nonfinancial awards received by employees either directly or indirectly. Extrinsic rewards at PT. Telecommunications Indonesia, Tbk. Witel Jatim Surabaya CCAN division measured with seven out of 11 indicators of (Robbins \& DeCenzo, 2002).

\section{Job Satisfaction}

Job satisfaction can be defined as an employee's emotional attitude towards a job. Job satisfaction at PT. Telecommunications Indonesia, Tbk. Witel Jatim Surabaya CCAN division is measured with 20 indicators of Minnesota Satisfaction Questionnaire (MSQ).

\section{Performance}

PerformanceA employee performance can be defined as the result of work in accordance with the company's provisions. Employee performance at PT. Telecommunications Indonesia, Tbk. Witel Jatim Surabaya CCAN division is measured by six indicators of (Ellinger et al., 2008)

\section{RESULTS AND DISCUSSION}

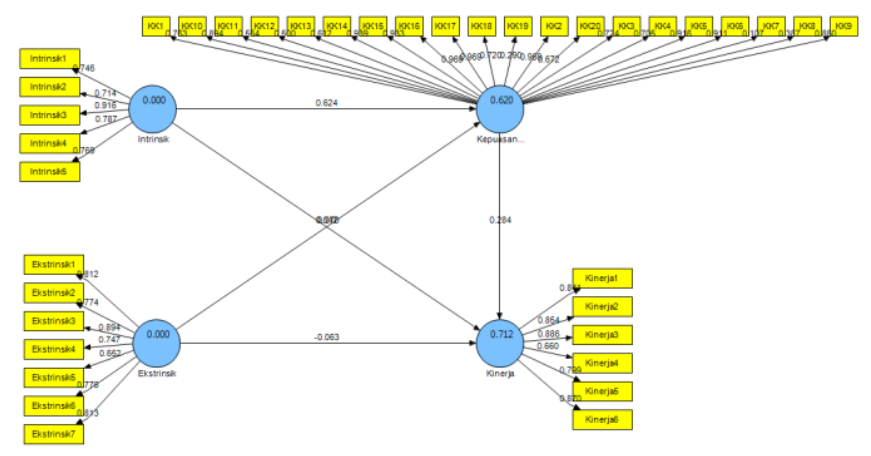

Figure 1

Outer Model Path Diagram Before Elimination 
Table 1

Outer Models (Weights or Loadings) Before

Elimination Validity

\begin{tabular}{|c|c|c|c|c|c|c|c|c|}
\hline \multirow{6}{*}{ Variabel } & \multirow{3}{*}{$\begin{array}{l}\text { Indikator } \\
\text { Intrinsik } 1 \\
\end{array}$} & \multirow{2}{*}{\multicolumn{2}{|c|}{$\begin{array}{c}\text { Nilai } \\
\begin{array}{c}\text { Convergent } \\
\text { Validity }\end{array} \\
\end{array}$}} & \multirow{2}{*}{ Description } & \multirow{5}{*}{$\begin{array}{l}\text { Intrinsic } \\
\text { Rewards }\end{array}$} & \multirow{2}{*}{$\begin{array}{l}\text { Intrinsik } 1 \\
\text { Intrinsik } 2\end{array}$} & \multirow{2}{*}{$\begin{array}{l}0.745183 \\
0.714317\end{array}$} & \multirow{2}{*}{$\begin{array}{l}\text { Valid } \\
\text { Valid }\end{array}$} \\
\hline & & & & & & & & \\
\hline & & 0.745950 & & Valid & & Intrinsik 3 & 0.915892 & Valid \\
\hline & Intrinsik 2 & 0.714384 & & Valid & & Intrinsik 4 & 0.787763 & Valid \\
\hline & Intrinsik 3 & 0.916034 & & Valid & & Intrinsik 5 & 0.769318 & Valid \\
\hline & Intrinsik 4 & 0.787279 & & Valid & \multirow{7}{*}{$\begin{array}{l}\text { Extrinsic } \\
\text { Rewards }\end{array}$} & Ekstrinsik 1 & 0.813586 & Valid \\
\hline & & & & & & Ekstrinsik 2 & 0.774347 & Valid \\
\hline \multirow{6}{*}{$\begin{array}{l}\text { Extrimsiansic } \\
\text { Rewaedsards }\end{array}$} & Ekstrinsik 1 & 0.812037 & Valid & & & Ekstrinsik 3 & 0.894532 & Valid \\
\hline & Ekstrinsik 2 & 0.773522 & Valid & & & Ekstrinsik 4 & 0.746350 & Valid \\
\hline & Ekstrinsik 3 & 0.893604 & Valid & & & Ekstrinsik 5 & 0.650014 & Valid \\
\hline & Ekstrinsik 4 & 0.747117 & Valid & & & Ekstrinsik 6 & 0.775414 & Valid \\
\hline & Ekstrinsik 5 & 0.652145 & Valid & & & Ekstrinsik 7 & 0.812822 & Valid \\
\hline & $\begin{array}{l}\text { Ekstrinsik } 6 \\
\text { Ekstrinsik } 7\end{array}$ & $\begin{array}{l}0.776445 \\
0.812715\end{array}$ & Valid & & \multirow{7}{*}{$\begin{array}{c}\text { Job } \\
\text { Satisfaction }\end{array}$} & KK 1 & 0.764304 & Valid \\
\hline \multirow{6}{*}{$\begin{array}{c}\text { Job } \\
\text { Satisfaction }\end{array}$} & KK 1 & 0.763019 & Valid & & & KK 2 & 0.960198 & Valid \\
\hline & KK 2 & 0.959157 & Valid & & & KK 3 & 0.718379 & Valid \\
\hline & KK 3 & 0.723991 & Valid & & & KK 4 & 0.702362 & Valid \\
\hline & KK 4 & 0.705073 & Valid & & & KK 5 & 0.916297 & Valid \\
\hline & Intrinsik 5 & 0.768945 & & Valid & & KK 6 & 0.911889 & Valid \\
\hline & & & & & & KK 9 & 0.864777 & Valid \\
\hline
\end{tabular}

In Table 4.1 above can be seen the results of data processing using PLS. Based on these results, there are three invalid indicators that have loading values below 0.5 namely KK7, KK8, and KK19. Because there are invalid indicators, the three indicators are eliminated and reprocessed with the data that has been eliminated.

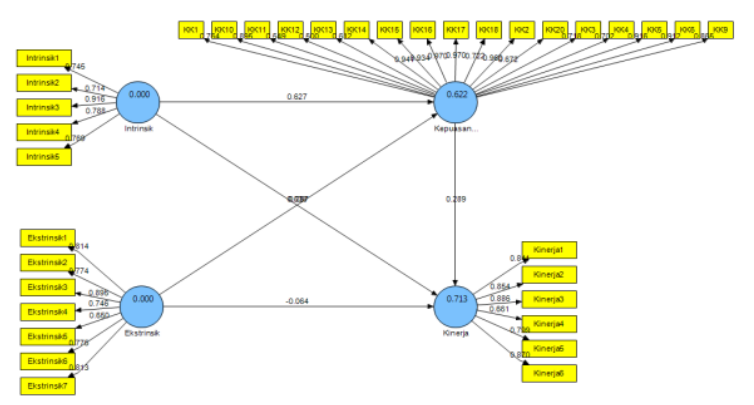

Source: Data processing by PLS, 2016. Figure 2

Source: Data processing by PLS, 2016. Figure 2 (Weights or Loadings) After Elimination

\begin{tabular}{cccc}
\hline Variabel & Indicators & \multicolumn{1}{c}{$\begin{array}{c}\text { Nilai } \\
\text { Convergent } \\
\text { Validity }\end{array}$} & Description \\
\hline & KK 10 & 0.894948 & Valid \\
\cline { 2 - 4 } & KK 11 & 0.548519 & Valid \\
\cline { 2 - 4 } & KK 12 & 0.500134 & Valid \\
\cline { 2 - 4 } Job & KK 13 & 0.612037 & Valid \\
\cline { 2 - 4 } Satisfaction & KK 14 & 0.941312 & Valid \\
\cline { 2 - 4 } & KK 15 & 0.933606 & Valid \\
\cline { 2 - 4 } & KK 16 & 0.969945 & Valid \\
\cline { 2 - 4 } & KK 17 & 0.969945 & Valid \\
\cline { 2 - 4 } & KK 18 & 0.722475 & Valid \\
\cline { 2 - 4 } & KK 20 & 0.672063 & Valid \\
\hline Performance & Kinerja 1 & 0.841166 & Valid \\
\hline
\end{tabular}




\begin{tabular}{lll} 
Kinerja 2 & 0.854066 & Valid \\
\hline Kinerja 3 & 0.886481 & Valid \\
\hline Kinerja 4 & 0.660732 & Valid \\
\hline Kinerja 5 & 0.798685 & Valid \\
\hline Kinerja 6 & 0.870287 & Valid \\
\hline
\end{tabular}

Source: Data processing by PLS, 2016.

The results of reprocessing data are in Table 2 above. Based on the table, it can be seen that all indicators have met the loading value limit which is above 0.5 . So it can be said that the collected data is all valid and has a good convergent validity.

Table 3 Composite Reliability

\begin{tabular}{ccc}
\hline Variabel & $\begin{array}{c}\text { Composite } \\
\text { Reliability }\end{array}$ & Description \\
\hline Intrinsic Rewards & 0.917240 & Reliabel \\
\hline Extrinsic Rewards & 0.891444 & Reliabel \\
\hline Job Satisfaction & 0.969985 & Reliabel \\
\hline Performance & 0.925374 & Reliabel \\
\hline Source: Data processing by PLS, 2016.
\end{tabular}

Based on Table 3, it can be seen that all constructs have a composite reliability value of more than 0.7 , so it can be said that all constructs are reliable.

\section{Table 4}

Path Coefficients

\begin{tabular}{|c|c|c|c|}
\hline & $\begin{array}{l}\text { Original } \\
\text { Sample }\end{array}$ & $\begin{array}{c}\text { T- } \\
\text { Statistics }\end{array}$ & Description \\
\hline $\begin{array}{l}\text { Intrinsic Rewards } \\
\text {-> Performance }\end{array}$ & 0.638257 & 4.913653 & Significant \\
\hline $\begin{array}{l}\text { Extrinsic Rewards } \\
\rightarrow>\text { Performance }\end{array}$ & $\begin{array}{c}- \\
0.063545\end{array}$ & 0.529539 & $\begin{array}{c}\text { No } \\
\text { Significant }\end{array}$ \\
\hline $\begin{array}{l}\text { Intrinsic Rewards } \\
\text {-> Job Satisfaction }\end{array}$ & 0.627242 & 6.905195 & Significant \\
\hline $\begin{array}{l}\text { Extrinsic Rewards } \\
\text {-> Job Satisfaction }\end{array}$ & 0.266864 & 2.144272 & Significant \\
\hline $\begin{array}{c}\text { Job Satisfaction -> } \\
\text { Performance }\end{array}$ & 0.288747 & 2.168696 & Significant \\
\hline
\end{tabular}

Source: Data processing by PLS, 2016

Based on Table 4.4 it can be concluded that intrinsic rewards have a positive and significant influence on performance, with a parameter coefficient value of 0.63 and a significance value of 4.91 greater than the critical limit value of 1.96 . Based on these results it can be concluded that hypothesis 1 is accepted. Furthermore, extrinsic rewards have a negative but insignificant effect on performance, with a parameter coefficient value of 0.063 and a significance value of 0.52 smaller than the critical limit of 1.96 . This, suggests that hypothesis 2 is rejected.

Intrinsic rewards have a positive and significant influence on job satisfaction, with a parameter coefficient value of 0.62 and a significance value of 6.9 which is greater than the critical limit of 1.96. Extrinsic rewards have a positive and significant influence on job satisfaction, with a parameter coefficient value of 0.26 and a significance value of 2.14 greater than the critical limit of 1.96. Furthermore, job satisfaction has a positive and significant influence on performance, with a parameter coefficient value of 0.28 and a significance value of 2.16 which is greater than the critical limit of 1.96. Based on these results it can be concluded that hypothesis 3 is accepted. Furthermore, it can also be concluded that hypothesis 4 is accepted.

Influence Intrinsic Rewards (X1) to Performance $(Y)$ Based on the results of research that has been done, shows that intrinsic rewards have a positive and significant effect on performance. Thus the hypothesis that states intrinsic rewards have a significant effect on performance is acceptable. All types of rewards (intrinsic and extrinsic) have a positive direct relationship to employee performance. Intrinsic rewards have a higher influence on employee performance than extrinsic rewards (Gohari dkk. 2013).

Intrinsic rewards are intangible rewards from companies inherent in employees. Awards such as providing freedom and flexibility / flexibility to employees while working can improve the ability of ccan contract employees in terms of managing their working time effectively. Employees also participate in decision making related to technical problems in the work so that they are able to resolve complaints from customers. The results showed that PT. Telecommunications Indonesia, Tbk. Witel Jatim Surabaya has implemented intrinsic rewards well to contract employees, especially in the CCAN division so as to improve their performance.

\section{Influence Extrinsic Rewards (X2) to}

Performance $(\mathrm{Y})$

Based on the results of research that has been done, it is known that extrinsic rewards have a negative but insignificant influence on performance. Thus the hypothesis that extrinsic rewards have a significant effect on performance is rejected. The results showed that extrinsic rewards were unable 
to improve performance directly with insignificant relationships. Different results from research conducted by Gohari (2013), showed that there is a positive direct relationship between extrinsic rewards to performance. Gohari also stated that the influence of extrinsic rewards on performance is less than the influence of inrinsic rewards on performance.

Extrinsic rewards are financial and nonfinancial awards given by the company to employees either directly or indirectly. The results of this study showed that the provision of extrinsic rewards conducted by PT. Telecommunications Indonesia, Tbk. Witel Jatim Surabaya such as incentives based on employee performance and overtime payments in accordance with the provisions are not able to improve employee performance directly. This can happen because of the frequent delay in providing overtime money as well as incentivizing contract employees, especially in ccan divisions that are considered by employees to be quite low.

Effect of Intrinsic Rewards (X1) on Performance ( $Y$ ) through Job Satisfaction ( $Z$ )

Based on the results of research that has been processed, intrinsic rewards have a positive and significant influence on job satisfaction, as well as the relationship between job satisfaction to performance that also has a positive and significant influence. The results showed that the three hypotheses that states intrinsic rewards affect performance by mediating job satisfaction are acceptable. The relationship of these three variables is partial mediation, because intrinsic rewards can affect performance both directly and by mediation of job satisfaction. The organization's rewards system often has a significant impact on employee job satisfaction levels. For many years, generally managers believed that a satisfied employee was always a good employee. In other words, if management can keep all employees happy, good performance will automatically follow (Byars, Lloyd. L. \& Rue, n.d.).

The results of the study showed that intrinsic rewards that have been given by PT. Telecommunications Indonesia, Tbk. Witel Jatim Surabaya to contract employees in ccan division can improve employee job satisfaction. The high employee satisfaction towards intrinsic rewards received has an impact on improving the performance of the employee itself. The higher the job satisfaction, the more likely workers are to have a positive attitude towards their work (Wang \& Feng, 2003). Employee performance can contribute to the long-term survival of a company (Ellinger et al., 2008).

Effect of Extrinsic Rewards (X2) on Performance ( $Y$ ) through Job Satisfaction (Z)

Based on the results of research that has been conducted, extrinsic rewards have a positive and significant influence on job satisfaction, as well as job satisfaction that also has a positive and significant influence on performance. The results showed that the four hypotheses that extrinsic rewards affect performance by mediating job satisfaction are acceptable.

Extrinsic rewards relationship to performance with job satisfaction mediation is full mediation. Job satisfaction is able to mediate in full (full mediation) the relationship between extrinsic rewards and performance, because extrinsic rewards have a negative and insignificant influence on performance. It shows that the need for variable job satisfaction as a mediator in extrinsic rewards relationship with performance. The higher the job satisfaction, the more likely workers are to have a positive attitude towards their work (Wang \& Feng, 2003).

The acceptance of the fourth hypothesis, can be the reason for the importance of ccan division contract employees at PT. Telekomunikasi Indonesia Tbk. Witel Jatim Surabaya is satisfied with the extrinsic rewards given by the company so that it can affect their performance. Smith et al. (Sarwar \& Abugre, 2013) states "the most accepted and common aspects of job satisfaction are satisfaction with wages, promotional opportunities, co-workers, supervision, and the job itself". Higher reward and employee satisfaction in the organization play a major role both in the promotion of employee job satisfaction and higher productivity within the organization paying attention to the extrinsic rewards given to employees so that employees feel satisfied so as to influence their performance.

\section{CONCLUSION}

Based on the results of data processing using Partial Least Square (PLS) analysis, it can be concluded as follows:

1. The first hypothesis stating that Intrinsic Rewards have a significant effect on Performance is accepted.

2. The second hypothesis that Extrinsic Rewards has a significant effect on Performance is rejected.

3. A third hypothesis states that Intrinsic Rewards affect Performance by mediation accepted Job Satisfaction. 
Intrinsic Rewards have a positive and significant influence on Job Satisfaction, and Job Satisfaction has a positive and significant influence on Performance. It can be concluded that Job Satisfaction is able to partially mediate the effect of Intrinsic Rewards on Performance.

4. The fourth hypothesis states that Extrinsic Rewards affect Performance by mediation accepted Job Satisfaction.

Extrinsic Rewards have a positive and significant influence on Job Satisfaction, as well as job Satisfaction has a positive and significant impact on Performance. Can be retrieved conclusion that Job Satisfaction is able to full mediation effect of Extrinsic Rewards on Performance

\section{REFERENCES}

Ajila, C., \& Abiola, A. (2004). Influence of Rewards on Workers Performance in an Organization. Journal of Social Sciences, 8, 7-12. https://doi.org/10.1080/09718923.2004.11892 397

Byars, Lloyd. L. \& Rue, L. W. 2008. (n.d.). Human Resource Management. (9th edit). McGraw-Hill Irwin:

Ellinger, A. E., Ketchen Jr, D. J., Hult, G. T. M., Elmadağ, A. B., \& Richey Jr, R. G. (2008). Market orientation, employee development practices, and performance in logistics service provider firms. Industrial Marketing Management, 37(4), 353-366.

McCormick \& J. Tifflin. (1979). Industrial Psychology. George, Allen \& Unwin.

Robbins, S. P., \& DeCenzo, D. A. (2002). Podstawy zarzä... dzania. Polskie Wydawnictwo Ekonomiczne.

Sarwar, S., \& Abugre, J. (2013). The influence of rewards and job satisfaction on employees in the service industry. The Business \& Management Review, 3(2), 22.

Stajkovic, A. D., \& Luthans, F. (1998). Self-efficacy and work-related performance: A metaanalysis. Psychological Bulletin, 124(2), 240.

Tuma, J. M., \& Pratt, J. M. (1982). Clinical child psychology practice and training: A survey. Vldots of Clinical Child \& Adolescent Psychology, 137(August 2012), 37-41. http://doi.org/10.1037/a0022390, Gobry, F. (1999). $\{$ T $\}$ his is a title. $\{M\} y$ Journal, $1,120-$ 130., Osment, S. E. (1980). T. A. of R. 12501550. ... and R. H. of L. M. and R. ... R. from http://scholar.

google.
com/scholar?hl=en\&btnG =Search\&q=intitle: $T$ $\mathrm{HE}+\mathrm{AGE}+\mathrm{OF}+\mathrm{REFORM}+125$.-

1550\#2\%5Cnhttp://scholar. google. com/scholar?hl=en\&btnG=S., Caprara, G., \& Fida, R. (2008). Longitudinal analysis of the role of perceived self-efficacy for self-regulated learning in academic continuance and achievement. ... of Educational ..., 100(3), 525-534. http://doi.org/10.1037/00220663.100.3.525, Shanker, S. (2003). Philosophy of science, logic and mathematics in the twentieth century. ... P. L. and N. Y. R. http://doi. org/10. 4324/978020302947., Marenbon, J. (1998). R. H. of P. I. ... P. L. and N. Y. R. http://doi. org/ 10 . 4324/978020306227., Pole, N., \& Ablon, J. (2002). Ideal control mastery technique correlates with change in a single case. ... Theory, Research, Practice ..., 39(1), 88-96. http://doi.org/10.1037//0033-3204.39.1.88,

Xu, S., \& Rajlich, V. (2005). Dialog-based protocol: An empirical research method for cognitive activities in software engineering. 2005 International Symposium on Empirical Software Engineering, ISESE 2005, 397-406. http://doi.org/10.1109/ISESE.2005.1541848, Polikovsky, S., Kameda, Y., \& Ohta, Y. (2009). Facial micro-expressions recognition using high speed camera and 3D-gradient descriptor. 3rd International Conference on Imaging for Crime Detection and Prevention (ICDP 2009), (February), P. http://doi. org/10. 1049/ic. 2009. 024., Papadimitriou, A., \& Cai, Y. (2011). What drives the choice of mixed methods designs? - An analysis of current higher education research publications. 7th Mixed Methods International Conference, (June)., Dunbar, K. N. (1998). Problem solving. A Companion to Cognitive Science, 289-298. Retrieved from http://psycnet.apa.org/psycinfo/1987-98523000, Kimin, A. (2012). The focusing-oriented approach applied to couple therapy. A Thesis Submitted for the Degree of Ph.D in the School of Education and Lifelong Learning, University of East Anglia, (June), 553., Explicit, M. I. (n. d. ). T. knowledge M. I. E. A. T. for T. F., Williams, L. L., Levine, J. B., Malhotra, S., \& Holtzheimer, P. (2004). The good-enough mentoring relationship. Acad. Psychiatry, 28(2), 111-115. http://doi.org/10.1176/appi.ap.28.2.111, Falzer, P. R., \& Garman, D. M. (2012). Evidence-based decision-making as a practicebased learning skill: a pilot study. Acad. 
Psychiatry,

36(2),

104-109.

http://doi.org/10.1176/appi.ap.10050082,

Carraccio, C. L., Benson, B. J., Nixon, L. J., \&

Derstine, P. L. (2008). From the educational bench to the clinical bedside: translating the Dreyfus developmental model to the learning of clinical skills. Academic Medicine: Journal of the Association of, 761-767. http://doi.org/10.1097/ACM.0b013e31817eb63 2, Feinstein, R. E., \& Yager, J. (2013). Advanced psychotherapy training: Psychotherapy scholars' track, and the apprenticeship model. Academic Psychiatry, 37(4), 248-253. http://doi.org/10.1176/appi.ap.12100174, Suddaby, R. O. Y. (2006). From the Editors: Academy of Management Journal, 49(4), 633642., Thompson, M. (2011). Ontological shift or ontological drift? Reality claims, epistemological frameworks, and theory generation in organization studies. Academy of Management Review, 36(4), 754-773. http://doi.org/10.5465/amr.2010.0070,

Keshav, S. (2007). How to Read a Paper. Work, 37(3), 83-84. http://doi.org/10.1145/1273445.1273458.

(2002). Middlesex University Doctor of Professional Studies. Studies in Higher Education.

Tuma \& Pratt, J. M. (1982). Clinical child psychology practice and training: A survey. Vdots of Clinical Child \& Adolescent Psychology, 137(August 2012), 37-41. http://doi.org/10.1037/a0022390, J. M., Gobry $1,120-130 ., F .(1999) .\{T\}$ his is a title. $\{M\} y$ J., Osment, S. E. (1980). T. A. of R. 1250$1550 . .$. and R. H. of L. M. and R. ... R. from http://scholar. google. com/scholar?hl=en\&btnG=Search\&q=intitle: $T$ $\mathrm{HE}+\mathrm{AGE}+\mathrm{OF}+\mathrm{REFORM}+125$.-

1550\#2\%5Cnhttp://scholar. google. com/scholar?hl=en\&btnG=S., Caprara \& Fida, R. (2008). Longitudinal analysis of the role of perceived self-efficacy for self-regulated learning in academic continuance and achievement. ... of Educational ..., 100(3), 525-534. http://doi.org/10.1037/00220663.100.3.525, G., Shanker logic and mathematics in the twentieth century. ... Philosophy. London and New York: Routledge. http://doi.org/10.4324/9780203029473, S. (2003). P. of science, Marenbon, J. (1998). R. H. of P. I. I. I. ... P. L. and N. Y. R. http://doi. org/10. 4324/978020306227., Pole \& Ablon, J. (2002). Ideal control mastery technique correlates with change in a single case. ... Theory, Research, Practice ..., 39(1), 88-96. http://doi.org/10.1037//0033-3204.39.1.88, N., Xu \& Rajlich, V. (2005). Dialog-based protocol: An empirical research method for cognitive activities in software engineering. 2005 International Symposium on Empirical Software Engineering, ISESE 2005, 397-406. http://doi.org/10.1109/ISESE.2005.1541848, S., Polikovsky Kameda, Y., \& Ohta, Y. (2009). Facial micro-expressions recognition using high speed camera and 3D-gradient descriptor. 3rd International Conference on Imaging for Crime Detection and Prevention (ICDP 2009), (February), P16-P16. http://doi.org, S., Papadimitriou \& Cai, Y. (2011). What drives the choice of mixed methods designs? - An analysis of current higher education research publications. 7th Mixed Methods International Conference, (June)., A., Dunbar 289-298. Retrieved from http://psycnet.apa.org/psycinfo/1987-98523000, K. N. (1998). P. solving. A. C. to C. S., Kimin University of East Anglia, (June), 553., A. (2012). T. focusing-oriented approach applied to couple therapy. A. T. S. for the D. of P. . in the S. of E. and L. L., Explicit, M. I. (n. d. ). T. knowledge M. I. E. A. T. for T. F., Williams Levine, J. B., Malhotra, S., \& Holtzheimer, P. (2004). The good-enough mentoring relationship. Acad. Psychiatry, 28(2), 111-115. http://doi.org/10.1176/appi.ap.28.2.111, L. L., Falzer \& Garman, D. M. (2012). Evidencebased decision-making as a practice-based learning skill: a pilot study. Acad. Psychiatry, 36(2), 104-109. http://doi.org/10.1176/appi.ap.10050082, P. R., Carraccio Benson, B. J., Nixon, L. J., \& Derstine, P. L. (2008). From the educational bench to the clinical bedside: translating the Dreyfus developmental model to the learning of clinical skills. Academic Medicine: Journal of the Association of, 761-76, C. L., Feinstein \& Yager, J. (2013). Advanced psychotherapy training: Psychotherapy scholars' track, and the apprenticeship model. Academic Psychiatry, 37(4), 248-253. http://doi.org/10.1176/appi.ap.12100174, R. E., Suddaby 49(4), 633-642., R. O. Y. (2006). F. the E.: A. of M. J., Thompson epistemological frameworks, and theory generation in organization studies. Academy of Management Review, 36(4), 754-773. http://doi.org/10.5465/amr.2010.0070, M. 
(2011). O. shift or ontological drift? R. claims, ... Keshav 37(3), 83-84. http://doi.org/10.1145/1273445.1273458, S. (2007). H. to R. a P. W. (2002). Middlesex University Doctor of Professional Studies. Studies in Higher Education.

Wang, H. M., \& Feng, W. W. (2003). Review on employee job satisfaction. Commercial Research, 9, 43-45.

Yarmand, H., Zulkifli, N. W. B. M., Gharehkhani, S.,
Shirazi, S. F. S., Alrashed, A. A. A. A., Ali, M. A. Bin, Dahari, M., \& Kazi, S. N. (2017). Convective heat transfer enhancement with graphene nanoplatelet/platinum hybrid nanofluid. International Communications in Heat and Mass Transfer, 88, 120-125. https://doi.org/https://doi.org/10.1016/j.icheat masstransfer.2017.08.010 